\title{
SER PROFESSOR DE ENFERMAGEM
}

Vilanice Alves de Araújo Püschel*

O que é ser professor de Enfermagem? O que é estar professor de Enfermagem? A tentativa de responder a essas perguntas nos remete a refletir sobre os significados dos dois verbos e dos sentidos que, pensando na profissão, expressam. Ser é verbo que denota existência, essência, pessoa, íntimo, enquanto estar significa encontrar-se em certo estado, condição, ou situação no tempo ou no espaço, como também exercer cargo ou função de [professor]. O último traz um sentido de transição temporal.

Para os já iniciados no papel de docente pode-se fazer outra pergunta: como você se tornou professor de Enfermagem? Aqui outro verbo pode ser considerado: tornar(-se) evidencia transformar(-se), estado ou transição, como em, parafraseando Pimenta('), "dormiu enfermeira e acordou professora de Enfermagem", como se o estado de sono tivesse o efeito mágico de produzir transformação na essência do ser que adormeceu.

O que se busca é mostrar que ser professor não é um estado mágico, mas exige preparo, formação, profissionalidade; isto porque é uma profissão que se faz na relação com seres em formação; seres que se tornarão os condutores da sociedade; na Enfermagem, seres do cuidado. Por isso, é necessário mais do que conhecimento específico, mas a formação no campo pedagógico.

Se perguntarmos qual professor o marcou, entre as dezenas que passaram por sua vida escolar, talvez você se lembre de um ou dois, os quais possivelmente extrapolaram o conhecimento da área. Porém, o marcaram por características de quem gostava do que fazia, interagia, se preocupava, conversava, estabelecia vínculo, compreendia, dava apoio, usava metodologias de ensino diferenciadas e instigava o desejo do conhecimento, da busca, da descoberta.

O que se pretende com essas breves reflexões? Estamos há dez anos da publicação das Diretrizes Curriculares Nacionais do Curso de Graduação em Enfermagem, há 15 da publicação da Lei de Diretrizes e Bases da Educação Nacional, e de tantos outros documentos publicados, como por exemplo, os do Fórum dos Pró-Reitores das Universidades Brasileiras. Quais foram os impactos dessas publicações na formação dos enfermeiros ou na formação dos professores de Enfermagem? É fato que muitos cursos estão em processo ou passaram por reorientação curricular. No entanto, ainda há predominância da metodologia tradicional de ensino, da figura do professor repassador [com exceções, é claro], de enfermeiros se tornando professores, sem o devido preparo pedagógico. Abrem-se aspas aqui para mencionar que os programas de pós-graduação que deveriam formar mestres, estão formando pesquisadores e que, salvo pequenas iniciativas, pouco se investe na formação do professor. Então, quem formará o professor e como se dará este processo?

Se pensarmos nos desafios postos na atualidade, entre eles a grande expansão dos cursos de Enfermagem no país (superior a $700 \%$ em dez anos); as crescentes demandas por saúde, impulsionadas pela mudança no perfil demográfico e epidemiológico da população; o novo perfil do jovem que chega à Universidade; as mudanças no mundo do trabalho em uma sociedade globalizada, que exige profissionais com competências para agir eficazmente em diferentes situações; há que se questionar: como estamos formando os enfermeiros? Eles saberão agir com competências? As Diretrizes Curriculares Nacionais preconizam a formação do enfermeiro crítico, reflexivo, transformador da realidade. Mas, estamos formando o enfermeiro com esse perfil?

Artigo publicado na Lancet, em 2010, por Frenk e colaboradores ${ }^{(2)}$, propõe reformas instrucionais e institucionais que promovam aprendizagem transformadora e educação interdependente por meio da aprendizagem informativa (aquisição de conhecimento e habilidades), da aprendizagem formativa (socialização dos estudantes em torno de valores) e transformadora (desenvolvimento de atributos de liderança, com o propósito de produzir agentes de mudança). Ressalta-se que o termo utilizado é aprendizagem. Explicitam esses autores a visão de que todos os profissionais de saúde de em todos os países deverão ser educados para mobilizar conhecimento, ter raciocínio crítico e conduta ética, e ser competente para participar de sistemas de saúde centrados no paciente e na população como membros de equipes localmente ágeis e globalmente conectados.

Sendo assim, para Libâneo ${ }^{(3)}$, as Instituições de Ensino Superior têm o papel de transmitir a cultura e a ciência, e o compromisso de formar sujeitos pensantes e críticos, com personalidade ética. É de se considerar, assim, que o desafio posto no papel de ser professor de Enfermagem deve ser ressignificado, pois a realidade demanda mudanças. Os jovens que aspiram ser enfermeiros precisam encontrar professores que tenham, na

Cogitare Enferm. 2012 Jan/Mar; 17(1):9-14 
essência do ensinar, o processo criativo, interativo para formar seres pensantes, capazes de aprender a ser, aprender a conviver, aprender a conhecer e aprender a fazer, como pilares de uma educação para o século XXI, que tem a Educação como um Tesouro a Descobrir (Jacques Delors).

*Enfermeira. Doutora em Enfermagem Professora do Departamento de Enfermagem Médico-Cirúrgica da Escola de Enfermagem da Universidade de São Paulo.

1 - Pimenta SG, Anastasiou LGC. Docência no ensino superior. v. 1 São Paulo: Cortez; 2002.

2 - Frenk J, Chen L, Bhutta ZA, Cohen J, Crisp N, Evans T, et al. Health professionals for a new century: transforming education to strengh health system in an interdependent world. Lancet. 2010;(376):1923-58.

3 - Libâneo JC. Conteúdos, formação de competências cognitivas em ensino com pesquisa: unindo ensino e modos de investigação. Cadernos de Pedagogia Universitária. São Paulo: Pró-Reitoria de Graduação da Universidade de São Paulo; 2009. v.11.

Cogitare Enferm. 2012 Jan/Mar; 17(1):9-14 


\section{BEING A LECTURER OF NURSING}

Vilanice Alves de Araújo Püschel*

What does it mean to 'be' a Nursing lecturer? The attempt to respond to this question leads us to reflect on the meanings of the two verbs ('ser' and 'estar') which can be used to phrase it in Portuguese, particularly in terms of what they express, bearing in mind the profession. 'Ser' is a verb which denotes existence, essence, entity and innateness, while 'estar' refers to being in a particular state, condition or situation, in time or space as well as meaning to practise a profession or work in a particular role as a [lecturer]. The last one also implies a feeling of transience.

For those already initiated in the teaching role, one may pose another question: how did you become ('tornarse') a nursing lecturer? Here, another verb may be considered, 'tornar-se', which means 'to transform a state or transition', as in, paraphrasing Pimenta ${ }^{(1)}$, "she fell asleep a nurse and woke up a Nursing lecturer", as if the state of sleep had the magical effect of producing a transformation in the essence of the being who had gone to bed.

The point is that being a lecturer is not a magical state, but one that demands preparation, training and professionalism; this because it is a profession which is forged in a relationship with beings in training, beings who in society will become leaders, who in Nursing will be 'beings of care'. For this, it is not just specific knowledge that is needed, but also training in the pedagogical field.

If asked which teacher made a mark on you, out of the dozens who passed through your schooldays, you might remember one or two, who possibly knew their subject inside out. What made the impression on you, however, was their characteristics - that they liked what they did, that they interacted, that they worried, conversed, built links, understood, gave support, used different teaching methodologies and kindled the desire for knowledge, for searching, for discovery.

What is intended with these brief reflections? Ten years have now passed since the publication of the National Curricular Directives for Nursing Undergraduate Courses, fifteen since the publication of the National Education Directives and Bases Law, and so many other documents published, such as, for example, those pertaining to the Brazilian Universities Vice-Presidents' Forum. What has the impact been of these documents on the training of nurses or the training of the Nursing lecturers? It is a fact that many courses are either in the process of curricular re-orientation or have already passed through it. In the meantime however, traditional teaching methodology and the figure of the lecturer as a passer-on of knowledge (with some exceptions, of course) still predominate, as does the process of nurses turning into lecturers without the necessary pedagogic training. Here - in brackets as it were - one might mention the post-graduate programs which should be producing masters, but instead turn out researchers and which, with a few exceptions, invest little in the training of their students to be lecturers. So - who shall form the lecturer, and how shall it be done?

If we think about the challenges we currently face, among them the huge expansion of Nursing courses in Brazil (over 700\% in ten years); the growing demands on Health, propelled by the change in the population's demographic and epidemiological profile, the new profile of young people arriving at university, the changes in the workplace in a globalized world, which demands professionals with competencies for acting effectively in a variety of situations, one has to ask: how are we training the nurses? Are they going to know how to act with competency? The National Curricular Directives advise that the nurse should be trained to be critical, reflexive, a transformer of reality. But are we producing nurses with this profile?

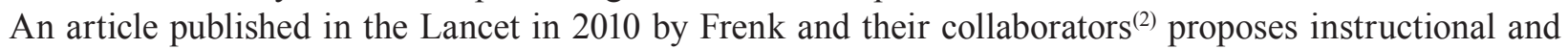
institutional reforms which promote transformative learning and interdependent education, through informative learning (the acquisition of knowledge and abilities), formative learning (socialization of students around values) and transformative learning (developing leadership characteristics, with the aim of producing agents of change). It stands out that the term used is 'learning'. These authors set out a vision, in which all health professionals, in all countries, have been trained to mobilize knowledge, have critical reasoning and ethical conduct, and are competent to participate in health systems which are centered on the patient and on the population, as members of teams which are locally agile and globally-connected.

This being so, for Libâneo ${ }^{(3)}$, Institutions of Higher Education have the role of transmitting culture and 
knowledge, and the duty to produce thinking, critical people, with ethical personalities. It follows that the challenge inherent to the role of being a lecturer must be resignified, seeing as how reality demands changes. The young who aspire to be nurses need to meet lecturers whose way of teaching is essentially creative, lecturers who interact to form thinking beings who can learn to be, learn to know and to do, lecturers who are pillars for a twenty-first-century education - lecturers with whom education is a treasure, waiting to be discovered (Jacques Delors).

*Nurse. PhD in Nursing. Professor in the Medical-Surgical Nursing Department of the São Paulo School of Nursing.

1 - Pimenta SG, Anastasiou LGC. Docência no ensino superior. v. 1 São Paulo: Cortez; 2002.

2 - Frenk J, Chen L, Bhutta ZA, Cohen J, Crisp N, Evans T, et al. Health professionals for a new century: transforming education to strengh health system in an interdependent world. Lancet. 2010;(376):1923-58.

3 - Libâneo JC. Conteúdos, formação de competências cognitivas em ensino com pesquisa: unindo ensino e modos de investigação. Cadernos de Pedagogia Universitária. São Paulo: Pró-Reitoria de Graduação da Universidade de São Paulo; 2009. v.11. 


\section{SER PROFESOR DE ENFERMERÍA}

Vilanice Alves de Araújo Püschel*

¿Qué es ser profesor de Enfermería? ¿Qué significa estar profesor de Enfermería? La tentativa de contestar a esas cuestiones hace reflexionar sobre los significados de eses dos verbos y de los sentidos que, pensando en la profesión, expresan. El ser es verbo que denota existencia, esencia, persona, íntimo, en cuanto el estar significa encontrarse en cierto estado, condición, o situación en el tiempo o espacio, así como ejercer cargo o función de [profesor]. Este último trae un sentido de transición temporal.

Ya para los iniciados en la función de docente, se puede hacer otra pregunta: ¿Cómo se volvió profesor de enfermería? Aquí otro verbo acerca del cual reflexionar: volverse evidencia, transformarse, estado o transición, como utiliza el autor Pimenta ${ }^{(1)}$, "durmió enfermera y despertó profesora de enfermería", como si el estado de sueño tuviera el efecto mágico de producir transformación en la esencia del ser que adormeció.

Lo que se busca mostrar es que ser profesor no es un estado mágico; es algo que exige preparación, formación, profesionalidad; es una profesión que se contruye en la relación con seres en formación; seres que se volverán los conductores de la sociedad; en la enfermería, seres del cuidado. Así, es necesario más que conocimiento específico, pero la formación en el campo pedagógico.

Se preguntamos a uno de cuál profesor tiene recuerdos entre las decenas que pasaron por su vida escolar, tal vez haya recuerdo de un o dos, los cuales posiblemente extrapolaron el conocimento del área. Sin embargo, las marcas se quedaron a causa de características que este le gustaba acerca de lo que el referido profesor hacía, como interaccionaba, se preocupaba, charlaba, establecía vínculo, comprendía, apoyaba, usaba metodologías de enseñanza diferenciadas e instigaba el deseo del conocimiento, de la búsqueda, del descubrimiento.

¿Qué se pretende con esas breves reflexiones? Tenemos diez años de la publicación de las "Diretrizes Curriculares Nacionais do Curso de Graduação em Enfermeragem", quince de la publicación de la "Lei de Diretrizes e Bases da Educação Nacional", así como de tantos otros documentos publicados, como, por ejemplo, los del "Fórum dos Pró-Reitores das Universidades Brasileiras". ¿Cuáles son los impactos de esas publicaciones en la formación de los enfermeros o en la formación de los profesores de enfermería? Es hecho que muchos cursos están en proceso o pasaron por reorientación curricular. Sin embargo, todavía predomina la metodología tradicional de enseñanza, de la figura del profesor que transmite [con excepciones, por supuesto], de enfermeros volviéndose profesores, sin una preparación pedagógica. Entre comillas, es importante decir que los programas de posgrado que deberían formar mestres están formando investigadores y que, con excepción de pequeñas iniciativas, poco es invertido en la formación del profesor. Entonces, ¿quién formará el profesor y cómo será ese proceso?

Si pensamos en los desafíos de la actualidade, como la grande expansión de los cursos de enfermería en el país (superior a 700\% en diez años); las crecientes demandas por salud, impulsionadas por el cambio en el perfil demográfico y epidemiológico de la población; el nuevo perfil del joven que llega a la Universidad; los cambios en el mundo del trabajo en una sociedad globalizada, que exige profesionales con competencias para actuar de modo eficaz en distintas situaciones; es importante cuestionar: ¿cómo estamos formando los enfermeros? ¿Ellos sabrán actuar con competencias? Las "Diretrizes Curriculares Nacionais" preconizan la formación de un enfermero crítico, reflexivo, transformador de la realidad. Pero, ¿estamos formando un enfermero con ese perfil?

Un artículo publicado en la Lancet, en 2010, por Frenk y colaboradores ${ }^{(2)}$, propone reformas instrucionales e institucionales que promuevan aprendizaje transformadora y educación interdependiente por medio del aprendizaje informativo (adquisición de conocimiento y habilidades), del aprendizaje formativo (socialización de los estudiantes acerca de valores) y transformadora (desarrollo de atributos de liderazgo, con el propósito de producir agentes de cambio). Se destaca que el término utilizado es aprendizaje. Los autores explicitan la visión de que todos los profesionales de salud en todos los países deberán ser educados para movilizar conocimiento, tener raciocinio crítico y conducta ética, así como ser competente para participar de sistemas de salud centrados en el paciente y en la población como miembros de equipos ágiles en el local y conectados globalmente.

De ese modo, para el autor Libâneo ${ }^{(3)}$, las Instituciones de Enseñanza Superior poseen el papel de transmitir la cultura y la ciencia, y el compromiso de formar sujetos pensantes y críticos, con personalidad ética. Hay que 
considerar, así, que el desafío de ser profesor de enfermería debe ser resignificado, ya que la realidad demanda cambios. Los jóvenes que desean ser enfermeros necesitan profesores que tengan, en la esencia del ensenãr, el proceso creativo, interactivo para formar seres pensantes, capaces de aprender a ser, aprender a convivir, aprender a conocer y aprender a hacer, como bases de una educación para el siglo XXI, que tiene la Educación como un Tesoro a Descubrir (Jacques Delors).

*Enfermera. Doctora en Enfermería. Profesora del Departamento de Enfermería Médico Quirúrgica de la Escuela de Enfermería de la Universidad de São Paulo.

1 - Pimenta SG, Anastasiou LGC. Docência no ensino superior. v. 1 São Paulo: Cortez; 2002.

2 - Frenk J, Chen L, Bhutta ZA, Cohen J, Crisp N, Evans T, et al. Health professionals for a new century: transforming education to strengh health system in an interdependent world. Lancet. 2010;(376):1923-58.

3 - Libâneo JC. Conteúdos, formação de competências cognitivas em ensino com pesquisa: unindo ensino e modos de investigação. Cadernos de Pedagogia Universitária. São Paulo: Pró-Reitoria de Graduação da Universidade de São Paulo; 2009. v.11.

Cogitare Enferm. 2012 Jan/Mar; 17(1):9-14 